\title{
Stem-cell projects falter
}

California's troubled economy has hit the state's ambitious stem-cell research programme, delaying the construction of facilities and disrupting recruitment.

At least three of the dozen groups that received a share of US\$271 million in building grants from the California Institute for Regenerative Medicine (CIRM) won't make the construction deadline of the end of 2010. And efforts to recruit stemcell researchers have stalled at some institutions, because of the delays in setting up lab space and because of university hiring freezes.

At the University of California Berkeley, administrators had hoped to recruit 15 principal investigators for a new \$160-million building, including two floors paid for with \$20 million from the CIRM. The building is on track to open in January 2011, "but we have no recruitments under way", says Mark Schlissel, the university's dean of biological sciences. "My real fear is that the University of California system and California will recover slower than the United States."

The CIRM was created by a statewide vote in 2004 to pump \$3 billion into stemcell research when President George W. Bush had restricted federal funding for work in the field. The initiative called for spending the money over a decade, so to help keep things on track, when the CIRM handed out building grants in May 2008, it required the projects to be completed within two years. That schedule is now in doubt for some.

In San Diego, the delay may stem from a decision by institutions to join forces. The CIRM gave \$43 million to the Sanford Consortium for Regenerative Medicine, which is made up of the historically competing Salk Institute for Biological Studies, the Scripps Research Institute, the Burnham Institute and the University of California, San Diego.

But because the consortium doesn't have a financial track record, officials say that it couldn't get a cost-effective loan to help finance its \$110-million building, and construction stalled. The group is now seeking a University of California guarantee for a $\$ \mathbf{6 0}$ million tax-exempt bond to underwrite construction so the facility can open in 2011. However, the university system is also experiencing its worst-ever financial stress (see Nature 460, 441; 2009).
Sanford consortium officials also negotiated with their major donor, South Dakota philanthropist Denny Sanford, to provide more money upfront. The group arranged to receive a promised gift from Sanford in a lump sum of $\$ 7.25$ million now instead of $\$ 10$ million later.

In Novato, the CIRM facility at the Buck Institute for Age Research has also run into delays. The institute was supposed to match $\$ 20.5$ million provided by the CIRM. But it couldn't raise the money and is now hoping to get the money from economic stimulus funds from the US National Institutes of Health. If that fails, the institute plans to seek a tax-exempt bond. The CIRM has given the institute a deadline of March 2010 to break ground or risk losing its grant.

As plans crawl along, university partners are gauging how this might affect recruitment. Lawrence Goldstein, stemcell research programme director at the University of California, San Diego, says that the roughly 15 stem-cell researchers recruited in recent years are becoming "landlocked". "Our young people need to expand their labs," he says.

In Santa Cruz, the University of California regents last month bailed the local campus out with $\$ 64$ million. That will help to pay for a bioscience building to include a stem-cell research floor partly funded by the CIRM. It, too, is behind schedule.

At the University of California, Irvine, administrators called for bids for a new \$61-million facility, which involved reusing a plan from an already constructed building. The competition for work was intense and, because it didn't involve new designs, the university ended up getting an extra, incomplete floor added to its building for no extra cost. Peter Donovan, co-director of the campus stem-cell programme, says he'd like to finish the floor and recruit for it too, but can't. "We committed to five stem-cell faculty hires," he says, "but recruitments now are frozen."

Nevertheless, the CIRM is pushing ahead to try to lure recruits in the tight fiscal environment. On 20 August its governing board approved $\$ 44$ million to bring new scientists to the state.

Rex Dalton

For more recession stories, see www.nature.com/ recessionwatch. 